\title{
Development and Assessment of Harmful Gases Reducing Molded Fuel Using Torrefied Wood ${ }^{1}$ (MPR
}

\author{
Chang-Goo $\mathrm{LEE}^{2} \cdot$ Chang-Deuk $\mathrm{EOM}^{2} \cdot$ Min-Ji KIM ${ }^{2} \cdot$ Seog-Goo KANG ${ }^{3, \dagger}$
}

\begin{abstract}
In this study, a torrefaction of Quercus serrata to manufacture a molded charcoal was performed, investigated material properties, fuel characteristics, and performed a quantitative analysis of hazardous gases which occur during a combustion process. In addition, a molded charcoal in market was selected as a control group, and a comparative analysis was performed. As a result, the higher heating value (HHV) of the torrefied specimen was about $14 \%$ higher than that of molded charcoal, and its ash content was about 51 times lower. Moreover, after performing a quantitative assessment of hazardous gases (carbon monoxide, nitrogen oxide, and sulfur dioxide) which were produced when each specimen was combusted for 900 seconds in an enclosed chamber, it was confirmed that the maximum value of generated amount of carbon monoxide on the torrefied specimen was about 50 times lower than that of the existing molded charcoal. Therefore, it was shown that the torrefied specimen produced in this study had a higher heating value than the molded charcoal in the market, and a very low amount of carbon monoxide generated during the combustion process.
\end{abstract}

Keywords: holed torrefied wood briquette, molded charcoal, higher heating value, elemental analysis, ash content, carbon monoxide

\section{INTRODUCTION}

The charcoal fuel for igniting commonly called 'beongaetan' in Korea is defined as 'molded charcoal for kindling holded-coal-briquette' which is molded to the holed coal briquette by combining bonding agent or coupling agent to sawdust charcoal in the Korea Forest Research Institute's notification 'Specification and Quality Standard of Wood Products'(no. 2020-1) [annex 14]. Materials such as charcoal or cokes, etc. are representative materials for facilitating surface combustion without flame, where incomplete combustion reaction occurs and carbon monoxide is producedas oxygen passes through a solid surface (Evans and Emmons, 1977). Since carbon monoxide is a colorless, tasteless and scentless gas, its combination power with hemoglobin in blood is about 200 250 times stronger than that of oxygen, it has a risk of degrading oxygen transporting capability of blood, causing suffocation (Armin et al., 1998; Weaver, 2009). Thus, if the molded charcoal is used in an indoor environment with limited oxygen supply for household heating or cooking,

${ }^{1}$ Date Received July 22, 2020, Date Accepted September 1, 2020

2 Department of Forest Products, National Institute of Forest Science, Seoul 02455, Republic of Korea

${ }^{3}$ Department of Biobased Materials, College of Agriculture and Life Science, Chungnam National University, Deajeon 34134, Republic of Korea

† Corresponding author: Seog-Goo KANG (e-mail: lachesis@cnu.ac.kr, ORCID: 0000-0002-2440-7070) 
the users might show delayed neuropsychiatric symptoms or die due to carbon monoxide addiction (Hampson et al., 1994; Kim et al., 2015; Kim et al., 2016). Furthermore, a recognition is formed that if the molded charcoal including so called 'beongaetan' that generates carbon monoxide is used for suicide, people could die without any pain, and suicide cases using the molded charcoal often occur in Asian countries such as Hong Kong, Taiwan, and Japan, etc. In case of Korea, it was known that the number of suicide cases using the molded charcoal is second to the cases of using drug, agricultural pesticides, and knives, etc. (Sung et al., 2015). In order to prevent suicides using the molded charcoal, measures for restricting its sales approach are being prepared, and a product property improvement study for reducing the carbon monoxide that occurs during the combustion process is being conducted (Lee et al., 2016; Kang et al., 2018).

Methods which could reduce the amount of carbon monoxide generated include a method of adding combustion promoting substance that facilitates a complete combustion of the charcoal as the main raw material, or a method of using an alternative combustion material besides the for a complete combustion.

Torrefied wood is an intermediate phase material between wood and charcoal, and refers to a material obtained after a relatively lower heat-treatment process of about $200 \sim 300^{\circ} \mathrm{C}$ in an anaerobic external condition (Bourgois and Guyonnet, 1988; Pourmaekhdomi, 2014). Because this torrefied wood has a relatively higher energy density than the wood at an initial state, and hydrophobic like charcoal, it is evaluated as an excellent fuel material. It is also being utilized as a briquette for cooking barbeque (Pach et al., 2002). Apart from this, its flexibility for various uses such as antioxidant, blended coagulants for water treatment, etc. is being mentioned, and it is being used as a study material for various perspectives (Nam et al., 2018; Yang et al., 2019; Park and Kang, 2020). As such, there is a proof that the torrefied wood has an excellent fuel characteristic along with the charcoal, and higher oxygen content and volatile matter than the charcoal theoretically. Thus, it could facilitate a relatively normal combustion to reduce the generation of carbon monoxide. It is necessary to explore a suitable alternative excluding starch, etc. which is used as the existing bonding agent.

Therefore, this study designated the main component of the molded charcoal as an alternative torrefied wood, and evaluated its feasibility as an alternative material. Considering the molded charcoal products being sold in the market mainly used broad-leaved species, the Quercus was selected, and torrefied to produce the main component. Moreover, evaluations were performed on its fuel performance when it was used in combination of natural combustion improver, as well as the amount of carbon monoxide generated among the harmful gases which emerge during the combustion process.

\section{MATERIALS and METHODS}

\subsection{Wood torrefaction}

The raw material used for torrefaction is a wood chip of quercus serrata (Thunb. Ex Murray) which is a hardwood species supplied from Namwon Forest Association located in Namwon, Jeollanam-do. The wood chips were dried at temperature of $105 \pm 3^{\circ} \mathrm{C}$ for over 48 hours. For torrefaction, a wood roaster which was built independently for this research was used, and the schematic diagram is shown in the Fig. 1. The circular frame of the system indicated in the schematic diagram is a reactor, and a rotary drive was rotating at the speed of $45 \mathrm{rpm}$ through a rotation axis located in the center of the reactor while oxygen from outside was blocked using a hydraulic cylinder. Then, the reactor was heated through a direct heat generated 


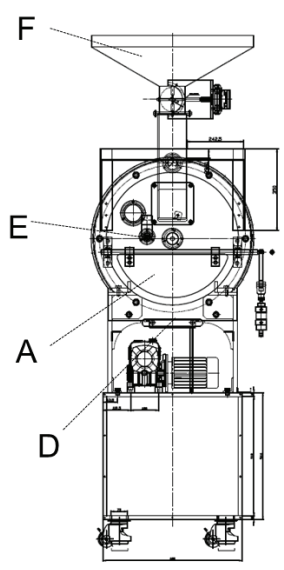

(a)

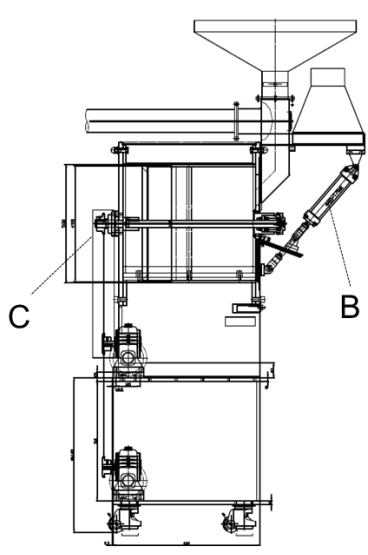

(b)
Fig. 1. Schematic diagram of wood roaster. (a) Front view, (b) side view. A: Reactor, B: hydraulic cylinder, $\mathrm{C}$ : axis of rotation, D: heat supply apparatus, E: thermocouple, F: feedstock inlet.

from a heat supply apparatus located at the bottom of the reactor. Once the internal temperature reached $220^{\circ} \mathrm{C}$, the wood chips were inserted by opening the upper hatch. The torrefaction time was set as $300 \mathrm{sec}-$ onds each, and the entire torrefied wood chips were pulverized using a mixer. The pulverized matter passed through $\# 8$ standard screen, and it was dried for over 48 hours at $105 \pm 3^{\circ} \mathrm{C}$ once again.

\subsection{Specimen}

\subsubsection{Adhesive}

For the material used as an adhesive for specimen production, gelatin solids extracted from protein of a pig (Deokyoung Gelatin, Pocheon in Gyeonggi-do) was purchased from a market and used. This is made up of $84 \sim 90 \%$ of protein, $8 \sim 12 \%$ of water, and $2 \sim 4 \%$ of mineral. Distilled water was combined with the gelatin solids to produce it as a liquid form, and mixed amount of the distilled water was set as twice the number of solids of gelatin. Then, the mixture was stored in a container, sufficiently stirred until the gelatin sol- ids are completely dissolved within a constant temperature water bath with the condition of $45 \pm 3^{\circ} \mathrm{C}$, and used as the adhesive of specimen.

\subsubsection{Forming and injection}

For forming and injection processes of the specimen, the self-produced hydraulic press was used. The target density of the specimen was $0.7 \mathrm{~g} / \mathrm{cm}^{3}$, and considering that the internal volume of 13-pin mold frame was $427.21 \mathrm{~cm}^{3}$, the gelatin solids content was set as $15 \mathrm{wt} \%$ in a torrefied wood dry weight of $300 \mathrm{~g}$. At this point, since the moisture content of gelatin solids was $12 \%$, the mixture was produced by considering moisture correction value. Then, the mixture was inserted in the 13-pin mold frame, pressure of $0.78 \mathrm{MPa}$ was applied. The gelatin adhesive was cold pressured for 600 seconds so that it could be hardened sufficiently at room temperature. These were collected, and cured for 168 hours at room temperature.

\subsubsection{Application and dry treatment of combustion promoting substance}

For the combustion promoting substance of the specimen, flaxseed oil, a dry fat oil contained in the seeds of flax, was purchased from the market and used (Daemyeong Chemicals Co., Ltd. Seoul). This is made up of $8 \sim 9 \%$ of saturated acid, $10 \sim 15 \%$ of oleic acid, $25 \sim 35 \%$ of linoleic acid, $35 \sim 45 \%$ of linolenic acid, $6.5 \%$ of oxygen, $0.5 \sim 1.5 \%$ of non-unsaponifiable matter, and $4.5 \%$ of glycerol. $20 \mathrm{~g}$ of flaxseed oil was applied on a single surface of the specimen after the room-temperature dry treatment was completed. Then, all specimens were dried for over 24 hours at $105 \pm 3^{\circ} \mathrm{C}$. In addition, as a control group of the specimen, molded charcoal (" $\mathrm{H}$ " company, Korea) purchased from the market was selected. The control group specimen was configured with charcoal powder, barium nitrate, potassium nitrate, and whole meal. The properties (mass, moisture content percentage, and 
Table 1. Physical properties of the specimens

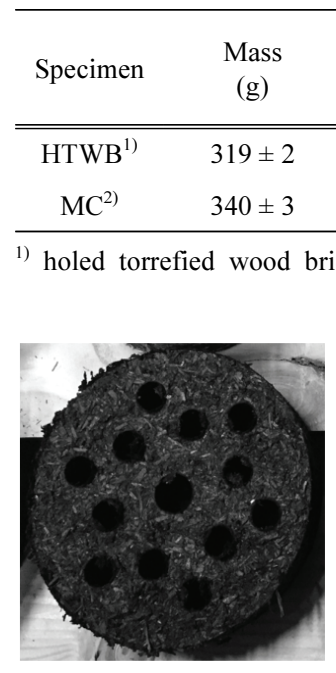

(a)

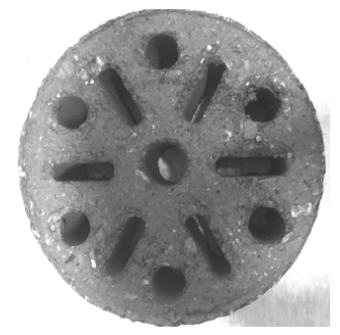

(b)
Fig. 2. Specimens. (a) Holed torrefied wood briquette, (b) molded charcoal.

density) and description of each specimen were indicated in the Table 1 and Fig. 2.

\subsection{Testing method}

\subsubsection{Elemantal analysis}

The elemantal analysis was conducted according to test standard ASTM D3176-74, and the test was performed through an elemental analyzer EA 1108 CHNS-O (FISON Instruments, USA). For the test condition, the powder specimen was instantaneously combusted in a pure oxygen atmosphere for oxidation, the generated gas compounds were separated by their components from a separation tube of the equipment, and a quantitative analysis was performed on $\mathrm{C}, \mathrm{H}, \mathrm{N}, \mathrm{S}$ among the specimen through TCD (thermal conductivity detector). At this point, $\mathrm{O}$ was generated by pyrolysis, transformed into carbon monoxide, and redetected by TCD again. The measurement was performed 3 times repeatedly, and the average value of each item was estimated.

\subsubsection{Ash content}

The ash content measurement was conducted by test standard ASTM D3174-04, and the test was performed through Muffle Furnace (CEBER CERAMIC FIB, USA). For the test method and condition, a crucible containing the specimen was inserted into the muffle furnace, and the internal temperature of the furnace was increased up to $250^{\circ} \mathrm{C}$ at speed of $4 \sim 5^{\circ} \mathrm{C} / \mathrm{min}$, and the crucible was left for 1 hour. Then, the temperature was increased (at approximately $9 \sim 10^{\circ} \mathrm{C} / \mathrm{min}$ ) to reach up to $800 \pm 25^{\circ} \mathrm{C}$ for 1 hour, and maintained that temperature for minimum of 2 hours. The crucible was removed from the furnace, left in the air for 300 600 seconds, cooled down to room temperature, and its weight was measured at $0.1 \mathrm{mg}$ level and recorded. The measurement was performed 3 times repeatedly, and the average value of the measurements was estimated.

\subsubsection{Higher heating value}

HHV (higher heating value) measurement was performed according to test standard ASTM D5865/ D5865M-19, and the test was performed through a cylinder-type calorimeter Parr 6400 (PARR INSTRUMENT INC., USA). At this point, the specimens which were pulverized by the mixer and passed through \#16 standard screen were used for both conditions, and temperature increase rate during the combustion process of the specimens by the cylinder-type calorimeter was measured to estimate HHV (MJ/kg). The measurement was performed 3 times repeatedly, and the average value of the measurements was estimated and indicated.

\subsubsection{Quantitative analysis of combustion gases}

In order to detect harmful gases content that emerge during the combustion process of each specimen, a combustion gases measurement test was performed as 
shown in the Fig. 3 below. After the specimen of each condition which was chelated in outdoor environment was fixed within $1,000 \times 1,300 \times 2,000 \mathrm{~mm}$ chamber, an air emission measuring instrument GREENLINE MK2 (EUROTRON, England) was used to capture the combustion gases of the specimen through an injection tube of the instrument, and measure the gases. Three gases were assessed, including carbon monoxide (CO), nitrogen oxide ( $\mathrm{NOx})$, and sulfur dioxide $\left(\mathrm{SO}_{2}\right)$. At this point, nitrogen dioxide $\left(\mathrm{NO}_{2}\right)$ was derived from measuring each carbon monoxide (NO) and nitrogen dioxide $\left(\mathrm{NO}_{2}\right)$ for 900 seconds. In order to perform a simulated experiment of conditions in which the molded charcoal distributed in the market was misused for suicide, this study carried in the ignited specimen in the chamber with oxygen concentration of $20.8 \%$, and sealed the chamber to perform the combustion gases emission measurement.

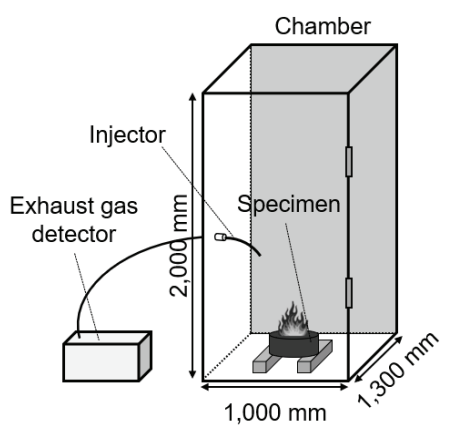

Fig. 3. Schematic diagram of experimental method. Each specimen has detected by a exhaust gas detector by gathered gas and passing through the injector in the chamber.

\section{RESULTS and DISCUSSION}

\subsection{Fuel characteristics}

Table 2 indicates the analysis results of elementary analysis, ash content and higher heating value. These measurement results were obtained in a condition where the torrefied specimen included the gelatin and flaxseed oil, and the molded charcoal available in the market included barium nitrate and potassium nitrate. Sulfur was not detected from the specimen in both conditions, and the carbon content was about $50 \%$, which indicated no big difference between the conditions. In contrast, for hydrogen and oxygen contents, it was revealed that the torrefied specimen had higher contents than the molded charcoal by approximately 2.6 and 2.2 times, respectively. On the other hand, the torrefied specimen had a lower nitrogen content than the molded charcoal distributed in the market by approximately 2.3 times.

The result of ash content indicated that the torrefied specimen had a lower content than the molded charcoal distributed in the market by about 51 times. It is determined that this result was indicated because the molded charcoal which is being distributed in the market has a relatively higher non-volatile matter, considering the fact that it includes approximately 25 $w t \%$ of the metal structural materials barium nitrate, and also the combustion promoting substance potassium nitrate and the adhesive whole meal, etc. along with hardwood charcoal.

Table 2. Analyzed result of the chemical properties and fuel characteristic

\begin{tabular}{ccccccc}
\hline Specimen & $\begin{array}{c}\text { Carbon } \\
(\%)\end{array}$ & $\begin{array}{c}\text { Hydrogen } \\
(\%)\end{array}$ & $\begin{array}{c}\text { Oxygen } \\
(\%)\end{array}$ & $\begin{array}{c}\text { Nitrogen } \\
(\%)\end{array}$ & $\begin{array}{c}\text { Ash } \\
(\%)\end{array}$ & $\begin{array}{c}\mathrm{HHV}^{1)} \\
(\mathrm{MJ} / \mathrm{kg})\end{array}$ \\
\hline \hline $\mathrm{HTWB}^{2)}$ & $49.99 \pm 0.47$ & $5.81 \pm 0.04$ & $41.04 \pm 0.43$ & $2.68 \pm 0.14$ & $0.48 \pm 0.17$ & $20.06 \pm 0.17$ \\
$\mathrm{MC}^{3)}$ & $48.27 \pm 0.08$ & $2.27 \pm 0.06$ & $18.86 \pm 0.12$ & $6.17 \pm 0.07$ & $24.43 \pm 0.15$ & $17.21 \pm 0.10$ \\
\hline
\end{tabular}

\footnotetext{
1) higher heating value, ${ }^{2)}$ holed torrefied wood briquette, ${ }^{3)}$ molded charcoal.
} 
The result of higher heating value indicated that the torrefied specimen had a higher value than the molded charcoal distributed in the market by about $14 \%$. According to a precedent study by Boley and Landers (1969), hardwood charcoal produced at temperature range of $571 \sim 650^{\circ} \mathrm{C}$ had carbon content of approximately $65 \sim 68 \%$, higher heating value of $23 \sim 25 \mathrm{MJ} / \mathrm{kg}$, and ash content of $15 \sim 17 \%$. Comparing these results with the molded charcoal in the market used in this study, despite its main component was hardwood charcoal, the carbon content and higher heating value were lower by $26 \sim 29 \%$ and $25 \sim 31 \%$, respectively, and ash content was higher by $30 \sim 39 \%$. These results are also considered to be due to the previously mentioned fact that molded charcoal includes metal structural materials of barium nitrate and other additives, thus it has less quantity of elements which could contribute to heating of hardwood charcoal, the main component. However, the ignition time of hardwood charcoal is more delayed than that of torrefied wood by approximately $50 \%$, and the hardwood is unable to facilitate flaming combustion independently (Lee, 2016).

Considering the fact that the molded charcoal shall add metal structural materials such as barium nitrate for the purpose of the product, it is determined that fuel performances of the torrefied specimen formed by using gelatin produced in this study and the combustion promoting substance flaxseed oil are more excellent.

\subsection{Combustion gases}

For the combustion phase of each specimen, the molded charcoal in the market caused flame combustion with combustion promoting substance such as barium nitrate, etc. at the time of ignition, and the combustion phase was changed to surface combustion, which stayed until the last session of the test. For the torrefied specimen on the other hand, it caused flame combustion until the last session of the test even after the ignition, and the combustion flame was close to dark red to red.

Fig. 4 shows the result of indicating the amount of carbon monoxide generated during the combustion process of each specimen by time unit. It was revealed that the amount of carbon monoxide generated from the molded charcoal in the market was increasing remarkably since the beginning of the combustion process, and this is determined to be caused by incomplete combustion reaction by surface combustion. In the qualitative analysis test of combustion gases, the maximum amount of carbon monoxide was $718 \mathrm{ppm}$ and $4,096 \mathrm{ppm}$ in the last 900 seconds session for torrefied specimen and molded charcoal in the market, respectively. The torrefied specimen showed approximately 50 times reduced effect compared to molded charcoal in the market. Tumuluru et al. (2010) reported that biomass of the same species has volatile matter content of carbide reduced as it has a high heat-treatment temperature, and a longer reaction time. In addition, the result of a study by Lee (2016) identified that a torrefied specimen of oak which includes gelatin and flaxseed oil has approximately $48 \%$ greater amount of carbide than the molded charcoal.

Considering each of these results, since the contents of the torrefied specimen contain a relatively larger amount of carbide than the molded charcoal in the market, it shows a relatively complete combustion reaction, and thus carbon monoxide content was remarkably lower.

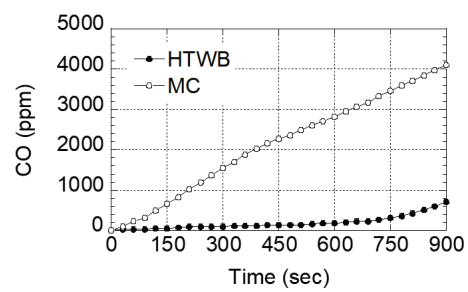

Fig. 4. Comparative results for the carbon monoxide. HTWB: Holed torrefied wood briquette, MC: molded charcoal. 


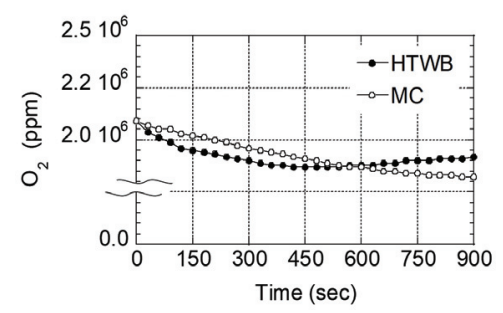

Fig. 5. Comparative results for the oxygen during the combustion process of each specimen.

HTWB: Holed torrefied wood briquette, MC: molded charcoal.

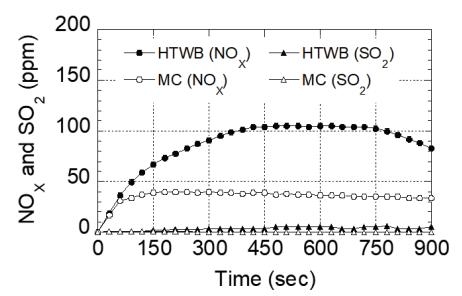

Fig. 6. Comparative results for the nitrogen oxide and sulfur dioxide.

HTWB: Holed torrefied wood briquette, MC: molded charcoal.

Furthermore, oxygen concentration in the chamber during the combustion process of each specimen was shown in the Fig. 5. Both specimens showed reduced oxygen concentration with the delayed combustion time. However, oxygen concentration of molded charcoal reduced gradually in a linear form until the end of the combustion test, while that of torrefied specimen reduced relatively rapidly in a curved form until approximately at 500 second, when the concentration was almost maintained.

Fig. 6 is the result of indicating the amount of nitrogen oxide and sulfur dioxide generated during the combustion process of each specimen by time unit. It was found that nitrogen oxide of torrefied specimen increased slowly as it drew a curved from since the beginning of combustion, and the amount was approximately 2 times larger than that of molded charcoal distributed in the market since it passed 200 seconds.
In contrary, nitrogen oxide of molded charcoal distributed in the market was revealed to indicate a lineal form since it passed 100 seconds, and the value was maintained after. The cause for this result is due to combustion phase (flame combustion and surface combustion) of each specimen. In addition, considering the fact that flame of the previously mentioned torrefied specimen was close to dark red to red, the flame temperature is determined to be approximately at $525 \sim 1,000^{\circ} \mathrm{C}$ (Stirling, 1905). Gadi et al. (2003) reported that the cause of high amount of NOx generated during the combustion process of biomass is due to flame combustion, and NO's thermoforming occurs due to reactions of atmospheric nitrogen and oxygen at high temperature. As such, it was determined that torrefied specimen having flame combustion phase had a relatively high amount of NO generated than molded charcoal distributed in the market, which has surface combustion phase. Moreover, it was revealed that the amount of sulfur dioxide generated was quite small or almost none for both specimens.

\subsection{The amount of carbon monoxide generated and human health hazard}

Next, the relationship between the carbon monoxide concentration and the human health hazard identifiedfrom studies by Struttmann et al. (1998) and Goldstein (2008) was cited to compare the amount of carbon monoxide generated in the two specimens of this study. These studies revealed that if the concentration of carbon monoxide is $3,200 \mathrm{ppm}$, people will show symptoms of headache, dizziness, and nausea within 5 to 10 minutes, and lead to death within 30 minutes if they are continuously exposed to such environment. As such, considering that the maximum value of the amount of carbon monoxide generated in the molded charcoal distributed in the market was 4,096 ppm, it means that people are highly likely to die within 30 minutes. On the other hand, the maximum value of 
the amount of carbon monoxide generated in the torrefied specimen was $718 \mathrm{ppm}$. According to a precedent study in the similar range, people show symptoms of dizziness, nausea, and convulsion within 45 minutes at $800 \mathrm{ppm}$, and lose bodily sensation within 2 hours, but still alive. The torrefied specimen manufactured as an alternative material of molded charcoal using torrefied wood (an intermediate material between wood and charcoal), protein-based gelatin adhesive and flaxseed oil (dry fatty oil) in this study has a far lesser amount of carbon monoxide generated during the combustion process than molded charcoal for roasting which is distributed in the market. Therefore, it is expected that even if it is misused for suicide, its success rate will be largely reduced.

\section{CONCLUSION}

This study used gelatin adhesive to cold press a wood chip of a torrefied oak for 300 seconds at $220^{\circ} \mathrm{C}$, and applied flaxseed oil to produce a specimen. The results of fuel characteristics and a quantitative assessment of combustion gases for comparing performances between the specimen and molded charcoal which is available in the market are as follows:

1. The carbon content of torrefied specimen was approximately $50 \%$, which had no big difference with that of molded charcoal in the market, and it was confirmed that the hydrogen and oxygen contents were 2.6 times and 2.2 times greater, respectively. The nitrogen content of torrefied specimen was about 2.3 times lesser than that of molded charcoal in the market.

2. It was revealed that the ash content of torrefied specimen was about 51 times lesser than that of molded charcoal in the market, and the higher heating value of torrefied specimen was confirmed to be about $14 \%$ larger.

3. Since the maximum value of the amount of car- bon monoxide generated in the specimen through the combustion process for 900 seconds was about 50 times lower than that of molded charcoal in the market, it was confirmed that it showed a quite large carbon monoxide reduction effect.

4. Considering the fact that people only experience sensory paralysis and no death even if they are exposed to the torrefied specimen of this study for 2 hours, it implies that even if this is misused for suicide, it could reduce the success rate.

\section{ACKNOWLEDGMENT}

This study was carried out with the support of 'R\&D Program for Forest Science Technology (Project No. 2018117B10-2020-AB01)' provided by Korea Forest Service (Korea Forestry Promotion Institute).

\section{REFERENCES}

ASTM D3174-04. 2010. Standard test method for ash in the analysis sample of coal and coke from coal. American Society for Testing and Materials, Pennsylvania, USA.

ASTM D3176-74. 2015. Standard method for ultimate analysis of coal and coke. American Society for Testing and Materials, Pennsylvania, USA.

ASTM D5865/D5865M-19. 2019. Standard test method for gross calorific value of coal and coke. American Society for Testing and Materials, Pennsylvania, USA.

Boley, C.C., Landers, W.S. 1969. Entrainment drying and carbonization of wood waste. Bureau of Mines, Washington DC, USA.

Bourgois, J, Guyonnet, R. 1988. Characterization and analysis of torrefied wood. Wood Science and Technology 22(2): 143-155.

Ernst, A., Zibrak, J.D. 1998. Carbon Monoxide Poisoning, The New England Journal of Medicine 339(22): 
1603-1608.

Gadi, R., Kulshrestha, U.C., Sarkar, A.K., Garg, S.C., Parashar, D.C. 2003. Emissions of $\mathrm{SO}_{2}$ and $\mathrm{NO}_{\mathrm{X}}$ from biofuel in India. Tellus 55(3): 787-795.

Goldstein, M. 2008. Carbon monoxide poisoning. Journal of Emergency Nursing 34(6): 538-542.

Hampson, N.B., Kramer, C.C., Dunford, R.G., Norkool, D.M. 1994. Carbon monoxide poisoning from indoor burning of charcoal briquets. Jama 271(1): 52-53.

Kang, C.H., Yoo, S.M., Kang, S.G. 2018. A study on development of wooden briquettes using torrefied wood powder manufactured by superheated steam and fuel characteristics depending on mixing ratio of anthracite coal. Journal of Korea Furniture Society 29(4): 284-295.

Kim, H.J., Chung, Y.K., Kwak, K.M., Ahn, S.J., Kim, Y.H., Ju, Y.S., Kwon, Y.J., Kim, E.A. 2015. Carbon monoxide poisoning-induced cardiomyopathy from charcoal at a barbecue restaurant: A case report. Annals of Occupational and Environmental Medicine doi: 10.1186/s40557-015-0063-2.

Kim, Y.J., Sohn, C.H., Oh, B.J., Lim, K.S., Kim, W.Y. 2016. Carbon monoxide poisoning during camping in Korea. Inhalation Toxicology 28(14): 719-723.

Lee, C.G. 2016. A study on eco-friendly agglomerated torrefied wood. Master's Thesis, Chungnam National University, Republic of Korea.

Nam, J.B., Oh, G.H., Yang, S.M., Lee, S.E., Kang, S.G. 2018. Evaluation of antioxidant activities of water extract from microwave torrefied oak wood. Journal of the Korean Wood Science and Technology 46(2): 178-188.

National Institute of Forest Science. 2020. Standard and specification of wood product (2020-1). National Institute of Forest Science.

Pach, M., Zanzi, R., Bjornbom, E. 2002. Torrefied Bio- mass a Subsitute for Wood and Charcoal. 6th Asia-Pacific International Symposium on Combustion and Energy Utilization Proc. Int. Conf., Kuala Lumpur, Malaysia, pp. 285-290.

Park, H.G., Kang, S.G. 2020. A study on the stability and sludge energy efficiency evaluation of torrefied wood flour natural material based coagulant. Journal of the Korean Wood Science and Technology 48(3): 271-282.

Pourmaekhdomi, A.A. 2014. Comparison of energy balances of steam explosion and torrefaction technologies. Master's Thesis, Lappeenranta University of Technology, Finland.

Stirling. 1905. A book of steam for engineers. Stirling Consolidated Boiler Company, New York, USA. Struttmann, T., Scheerer, A., Prince, T.S., Goldstein, L.A. 1998. Unintentional carbon monoxide poisoning from an unlikely source. The Journal of the American Board of Family Practice 11(6): 481-484.

Sung, T.M., Jo, J.I., Ahn, P.S. 2015. A case study of verifying a suicide by carbon monoxide intoxication committed by burning an ignition charcoal briquette. Analytical Science and Technology 28(6): 398-408.

Tumuluru, J.S., Sokhansanj, S., Wright, C.T. 2010. Biomass torrefaction process review and moving bed torrefaction system model development. No. INL/EXT-10-19569, Idaho National Laboratory.

Weaver, L.K. 2009. Carbon monoxide poisoning. The New England Journal of Medicine 360(12): 1217-1225.

Yang, S.M., Lee, S.E., Park, H.G., Kang, S.G. 2019. A study on the impacts of paste type torrefied wood flour coagulants on water ecosystem. Journal of the Korean Wood Science and Technology 47(6): 709-720. 


\title{
APPENDIX
}

\author{
(Korean Version)
}

\section{반탄화목재를 이용한 유해가스 저감형 성형연료의 개발 및 평가}

초록 : 본 연구에서는 졸참나무를 반탄화 처리 후 성형숯 형태로 제작하여 물성과 연료특성 및 연소과정에서 발생되는 유해가스 정량분석을 수행하였다. 또한, 대조군으로 시중에서 유통 중인 구이용 성형숯을 선정하여 비교분석하였다. 그 결과, 반탄화 시험편의 고위발열량은 구이용 성형솣 보다 약 $14 \%$ 높았으며, 회분함량은 약 51 배 낮았다. 또한, 밀폐된 챔버에서 각각의 시험편을 $900 \mathrm{~s}$ 간 연소시켰을 때 발생되는 유해가스(일산화탄소, 질산화합물, 이산화황)를 정량평가한 결과, 반탄화 시험편에서 발생한 일산화탄소의 발생량의 최대값이 기존 성형숯보다 약 50 배 낮은 것으로 확인되었다. 따라서, 본 연구에서 제작한 반탄화 시험편이 시중 성형솣보다 고위발열량이 높고 연소과정에서 일산화탄소 발생량이 현저히 적은 것으로 나타났다.

\section{1. 서 론}

우리나라에서 흔히 일컫는 ‘번개탄’이란, 국립산림과학원 고시 ‘목재제품의 규격과 품질기준'(제2020-1호) [부속서 14]에서 톱밥숯에 결합제 혹은 착화제를 혼합하여 구멍탄형으로 성형한 '구멍탄착화용 성형숯'으로 정의되고 있다. 숯이나 코크스 등과 같은 물질은 표면에서 불꽃 없이 연소하는 표면연소를 촉진하는 대표적인 물질로써 산소가 고체 표면을 통과함에 따라 불완전연소반응이 촉진되며 일산화탄소가 발생한다(Evans and Emmons, 1977). 일산화탄소는 무색, 무취 및 무미의 기체로 인체 내 혈액 중 헤모글로빈과 결합하는 힘이 산소에 비해 약 200 250배 강하기 때문에 혈액의 산소 운반능력을 저해시켜 질식사를 초래할 위험이 있다(Armin et al., 1998; Weaver, 2009). 따라서 성형숯을 산소공급이 제한된 실내에서 가정용 난방이 나 조리용으로 이용할 경우 일산화탄소 중독에 의해 지연성 신경정신과적 증상을 나타내거나 사망에 이를 수 있다(Hampson et al., 1994; Kim et al., 2015; Kim et al., 2016). 또한 일산화탄소를 생성하는 일명 번개탄을 비롯한 성형숯은 자살용도로 이용할 시 고통 없이 사망할 수 있다는 인식이 형성되어 있어 성형숯을 이용한 자살사례가 홍콩, 대만, 일본 등의 아시아권에서 종종 발생되고 있다. 우리나라의 경우, 성형솣을 이용한 자살사례가 약물, 농약 및 칼 등에 의한 사례 다음으로 높다고 알려져있다 (Sung et al., 2015). 성형숯을 이용한 자살 예방을 위해 판매접근을 제한하는 대책방안을 마련하고 있으며, 성형솣의 연소과정에 서 발생되는 일산화탄소를 저감시키기 위한 제품물성 개선연구가 이어지고 있다(Lee et al., 2016; Kang et al., 2018).

일산화탄소 발생량을 저감시킬 수 있는 방안으로는 주원료인 숯의 완전연소를 촉진시키는 조연제를 첨가하는 방법 혹은 완전연소를 촉진시키는 숯 대체물질의 연소재를 사용하는 방법이 있다.

반탄화목재란 목재와 솣의 중간단계 물질로써 무산소의 외부조건에서 약 $200 ~ 300^{\circ} \mathrm{C}$ 의 비교적 낮은 탄화과정을 거쳐 얻어진 재료를 일컫는다(Bourgois and Guyonnet, 1988; Pourmaekhdomi, 2014). 이러한 반탄화목재는 초기상태의 목재에 비해 에너지 밀도가 높고 숯과 같이 소수성이기 때문에 우수한 연료재로 평가되고 있으며 특히 바비큐 조리용 브리켓으로도 활용되고 있다(Pach et al., 2002). 이 밖에도 항산화제, 수처리용 혼합응집제 등의 다양한 용도로의 이용 가능성에 대해 언급되고 있으며, 다양한 관점에서의 연구소재로 이용되고 있다(Nam et al., 2018; Yang et al., 2019; Park and Kang, 2020). 이와 같이 반탄화목재 는 숯과 더불어 우수한 연료적 특징을 가진다는 근거를 포함하여 이론적으로 숯보다 높은 산소함량 및 휘발성분을 가지기 때문에 비교적 정상연소를 촉진시킬 수 있어 일산화탄소의 생성을 저감시킬 수 있으므로 기존 결합제로서 이용되는 전분 등을 제외한 알맞은 대체 도입제의 탐색이 필요하다.

따라서 본 연구에서는 성형숯의 주원료를 대체 반탄화목재로 하여 대체재로서의 실현 가능성을 평가하였다. 이에 시중에서 판매되고 있는 성형솣 제품의 수종이 주로 활엽수종을 이용한다는 점을 고려하여, 활엽수종인 한국산 졸참나무를 선정하여 이를 반탄화처리 후 성형숯의 주원료로 제작하고 천연계 조연제와 혼합하여 이용하였을 때의 연료적 성능과 연소과정에서 발생되는 유해가스 중 일산화탄소 발생량의 평가를 실시하였다.

\section{2. 재료 및 방법}

2.1. 반탄화목재

반탄화처리에 이용된 원료는 전남 남원에 위치한 남원산림조합으로부터 공급받은 활엽수종인 졸참나무(Quercus serrata 


\section{Chang-Goo LEE $\cdot$ Chang-Deuk EOM $\cdot$ Min-Ji KIM $\cdot$ Seog-Goo KANG}

Thunb. ex Murray) 목재칩이다. 목재칩은 강제 송풍식 건조처리기를 이용하여 $105 \pm 3^{\circ} \mathrm{C}$ 에서 $48 \mathrm{~h}$ 이상 건조하였다. 반탄화처리 는 자체 제작한 급속목재탄화기(wood roaster)를 이용하였으며 그 모식도를 Fig. 1에 나타내었다. 모식도에서 나타낸 설비의 원형프레임은 반응로이며 이는 유압실린더를 이용하여 외부로부터 산소를 차단한 상태에서 반응로 중심에 위치한 회전축을 통해 $45 \mathrm{rpm}$ 의 속도로 회전구동을 실시하였다. 이후 반응로 하단에 위치한 열공급 장치에서 발생되는 직화열을 통해 반응로를 가열시켜 내부 온도를 $220^{\circ} \mathrm{C}$ 에 도달하였을 때 상단의 원료투입구를 개방하여 목재칩을 투입하였다. 반탄화 처리시간은 각각 $300 \mathrm{~s}$ 로 선정하여 실시하였으며 이후 전량의 반탄화 목재칩은 가정용 믹서를 이용하여 분쇄하였다. 분쇄물은 \#8표준체를 통과한 파티클을 이용하였으며 이를 다시 $105 \pm 3^{\circ} \mathrm{C}$ 의 강제 송풍식 건조기를 통해 $48 \mathrm{~h}$ 이상 건조하였다.

\section{2. 시험편}

\subsection{1. 접착제 제조}

시험편 제조를 위한 접착제로 이용된 재료는 돼지의 단백질로부터 추출된 젤라틴고형분(덕영젤라틴, 경기도 포천)을 시중에 서 구입하여 이용하였다. 이는 84 90\%의 단백질과 $8 \sim 12 \%$ 의 수분 그리고 $2 \sim 4 \%$ 의 무기염류로 구성되어 있다. 젤라틴고형분 에 증류수를 혼합하여 액상형태로 제조하였으며, 증류수의 혼합양은 젤라틴의 고형분 대비 2 배로 하였다. 이후 혼합물을 용기에 담아 $45 \pm 3^{\circ} \mathrm{C}$ 조건의 항온수조 내에서 젤라틴 고형분이 완전히 용해될 때 까지 충분히 교반한 후 이를 시험편의 접착제로 이용하였다.

\subsection{2. 성형 및 사출 공정}

시험편의 성형 및 사출을 위해 자체 제작한 유압 프레스를 이용하였다. 시험편의 목표밀도는 $0.7 \mathrm{~g} / \mathrm{cm}^{3}$ 이었으며, 13 핀 금형 프레임의 내부피가 $427.21 \mathrm{~cm}^{3}$ 인 점을 고려하여 반탄화목분 건조중량 $300 \mathrm{~g}$ 에 젤라틴고형분 함유량을 $15 \mathrm{wt} \%$ 로 하였다. 이때 젤라틴고형분의 함수율이 $12 \%$ 인 점을 고려하여 수분보정 값을 고려하여 교반물을 제조하였다. 이후 13 핀 금형 프레임에 교반물 을 투입한 후 $0.78 \mathrm{MPa}$ 의 압력을 가하여 젤라틴 접착제가 충분히 상온에서 경화될 수 있도록 $600 \mathrm{~s}$ 간 냉압처리 하였으며 이를 회수한 후 $168 \mathrm{~h}$ 동안 상온에서 양생하였다.

\subsection{3. 조연물질 도포 및 건조처리}

시험편의 조연물질로써 아마의 씨에 함유되어 있는 건성 지방유인 아마인유를 시중에서 구입하여 이용하였다((주)대명케미 칼, 서울). 이는 8 $~ 9 \%$ 의 포화산, $10 \sim 15 \%$ 의 올레산, $25 \sim 35 \%$ 의 리놀레산, $35 \sim 45 \%$ 의 리놀렌산, $6.5 \%$ 의 산소, $0.5 \sim 1.5 \%$ 의 비(非)비누화물 그리고 $4.5 \%$ 의 글리세롤기로 구성되어 있다. 상온건조가 완료된 시험편의 한 면에 아마인유 $20 \mathrm{~g}$ 를 각각 도포하였다. 이후 모든 시험편은 $105 \pm 3^{\circ} \mathrm{C}$ 의 강제 송풍식 건조기에서 $24 \mathrm{~h}$ 이상 건조된 것을 본 연구의 공시재료로 이용하였다. 그리고 본 시험편의 대조군으로써 시중에서 구입한 구이용 성형숯( $\mathrm{H}$ 사, 한국)을 선정하였다. 대조군 시험편의 구성은 참솣가루, 질산바륨, 질산칼륨, 소맥분이었다. 각 시험편의 물성(질량, 함수율, 밀도)과 성상을 Table 1과 Fig. 2에 나타내었다.

\section{3. 실험 방법}

2.3.1. 원소분석

원소분석은 시험규격 ASTM D3176-74에 의해 실시되었으며, 실험은 원소분석기 EA 1108 CHNS-O(FISON Instruments, USA)를 통해 수행하였다. 실험조건은 미량의 분말 시료를 순수 산소분위기에서 순간 연소시켜 산화시킨 후 생성된 가스 혼합물 을 기기의 분리관에서 성분별로 분리한 후 열전도도 검출기(TCD: Thermal conductivity detector)를 통해 시료 중의 $\mathrm{C}, \mathrm{H}$, $\mathrm{N}, \mathrm{S}$ 를 정량 분석을 실시했다. 이때 $\mathrm{O}$ 는 열분해하여 생성시킨 후 일산화탄소로 전환시켜 분리한 후 다시 열전도도 검출기로 검출하였다. 측정은 3 반복으로 실시하였으며, 각 항목에 대한 평균값을 산출하였다.

\subsection{2. 회분함량 측정}

회분함량 측정은 시험규격 ASTM D3174-04에 의해 실시되었으며, 실험은 회화로 Furnace(CEBER CERAMIC FIB, USA) 를 통해 수행하였다. 실험 방법 및 조건은 시료를 담고 있는 도가니를 회화로에 넣은 후 회화로 내부의 온도를 $4 \sim 5^{\circ} \mathrm{C} / \mathrm{min}$ 의 속도로 $250^{\circ} \mathrm{C}$ 까지 승온하고, $1 \mathrm{~h}$ 방치한다. 그 다음으로 $1 \mathrm{~h}$ 동안 $800 \pm 25^{\circ} \mathrm{C}$ 에 도달하도록 승온시켜 $\left(\right.$ 약 $\left.9 \sim 10^{\circ} \mathrm{C} / \mathrm{min}\right)$ 그 온도에서 최소 $2 \mathrm{~h}$ 동안 유지한다. 이후 회화로에서 도가니를 제거하고, 300 600 s간 대기 중에서 방치한 후 상온까지 냉각 시켜 $0.1 \mathrm{mg}$ 수준에서 무게를 측정하고 기록하였다. 측정은 3 반복으로 실시하였으며 이에 대한 평균값을 산출하였다. 


\subsection{3. 고위 발열량 측정}

고위 발열량(HHV, higher heating value) 측정은 시험규격 ASTM D5865/D5865M-19에 의해 실시되었으며, 실험은 봄베형 열량계 Parr 6400(PARR INSTRUMENT INC., USA)를 통해 수행되었다. 이때 시료는 2가지 조건 모두 가정용 믹서를 통해 분쇄하여 \#16 표준체를 통과한 것을 이용하였으며 봄베형 열량계를 통해 시료가 연소되는 동안의 온도 상승률을 측정한 후 시료의 고위 발열량 $(\mathrm{MJ} / \mathrm{kg})$ 를 구하였다. 측정은 3 반복으로 실시하였으며 이에 대한 평균값을 산출하여 나타내었다.

\subsection{4. 연소가스 정량분석}

각 시험편의 연소과정에서 발생되는 유해가스 함량을 검출하기 위해 아래 Fig. 3 과 같이 연소가스 측정시험을 실시하였다. 외부에서 착화시킨 각 조건의 시험편을 $1,000 \times 1,300 \times 2,000 \mathrm{~mm}$ 의 챔버 내에 고정시킨 후 대기배출가스측정기 GREENLINE MK2(EUROTRON, England)를 이용하여 시험편의 연소가스를 측정기의 주입관을 통해 포집하여 측정하였다. 측정항목은 일산화탄소 $(\mathrm{CO})$, 질소산화물 $\left(\mathrm{NO}_{\mathrm{x}}\right)$, 이산화황 $\left(\mathrm{SO}_{2}\right)$ 의 세 가지를 평가하였다. 이때 질소산화물( $\left.\mathrm{NO}_{\mathrm{x}}\right)$ 은 일산화질소(NO)와 이산 화질소 $\left(\mathrm{NO}_{2}\right)$ 를 각각 $900 \mathrm{~s}$ 간 측정한 후 합계 산출하였다. 본 연구에서는 시중에서 유통되고 있는 성형숯을 이용하여 실제로 자살용도로 악용하는 조건을 모의 실험하기 위하여, 산소농도가 $20.8 \%$ 인 챔버 내에 착화된 시험편을 반입한 후, 챔버를 밀폐시 켜 연소가스 배출량 측정실험을 실시하였다.

\section{3. 결과 및 고찰}

\section{1. 연료적특성}

Table 2에 원소분석, 회분함량 및 고위발열량에 대한 분석결과를 나타내었다. 반탄화 시험편은 젤라틴과 아마인유를, 시중 성형숯은 질산바륨과 질산칼륨 그리고 소맥분을 포함하고 있는 상태에서의 측정결과이다. 두 가지 조건의 시험편에서 황은 모두 검출되지 않았으며, 탄소함량은 약 $50 \%$ 정도로 서로 간의 큰 차이가 없었다. 이에 반해, 수소함량과 산소함량의 경우, 반탄화 시험편이 시중 성형숯 보다 각각 약 2.6배, 2.2배 높은 것으로 나타났다. 이에 반해 질소함량은 반탄화 시험편이 시중 성형숯 보다 약 2.3 배 낮은 것으로 나타났다.

회분함량의 결과는, 반탄화 시험편이 시중 성형숯보다 약 51 배 낮은 것으로 나타났는데, 이는 시중에 유통되고 있는 구이용 성형숯은 금속계 착화제인 질산바륨이 약 $25 \mathrm{wt} \%$ 함유되어 있다는 점과 그 외에 조연제인 질산칼륨과 접착제인 소맥분 등의 성분도 참숯과 함께 혼합되어 있다는 점을 고려해볼 때 비교적 불휘발분함량이 높기 때문에 이와 같은 결과를 나타낸 것으로 판단된다.

고위발열량의 결과에서는, 반탄화 시험편이 시중 성형숯보다 약 $14 \%$ 높은 것으로 나타났다. Boley and Landers (1969)의 선행연구에 따르면 $571 \sim 640^{\circ} \mathrm{C}$ 에서 제조된 참숯의 탄소함량은 약 $65 \sim 68 \%$ 이며 고위발열량은 $23 \sim 25 \mathrm{MJ} / \mathrm{kg}$ 이고 회분함량은 $15 \sim 17 \%$ 인 것으로 보고된 바 있으며, 이를 본 연구의 시중 성형숯과 비교해볼 때, 주원료가 참숯임에도 불구하고 탄소함량은 $26 \sim 29 \%$, 고위발열량은 $25 \sim 31 \%$ 낮으며, 회분함량은 30 39\% 높은 것으로 나타났다. 이러한 현상 또한 위에서 언급한 구이용 성형숯은 금속물질인 질산바륨을 비롯한 기타 첨가제를 함유하고 있으므로, 주원료인 참숯의 발열에 기여할 수 있는 원소의 양이 적기 때문인 것으로 사료된다. 그러나, 참숯의 착화시간은 참나무 반탄화 목재보다 약 $50 \%$ 지연되며 참숯 단독으로 불꽃연소 를 촉진할 수 없다(Lee, 2016). 성형숯은 제품의 용도상 반드시 질산바륨과 같은 착화제를 첨가해야 하는 점을 고려해볼 때, 본 연구에서 제조한 젤라틴을 이용하여 성형한 반탄화 시험편과 조연제인 아마인유의 연료적 성능이 더 우수하다고 판단된다.

\section{2. 연소가스}

각 시험편의 연소양상은 시중 성형숯의 경우, 착화당시 질산바륨 등의 조연물질에 의해 불꽃연소를 일으킨 후 표면연소의 양상으로 전환되어 실험 마지막 구간까지 유지되었다. 한편, 반탄화 시험편의 경우 착화 후에도 실험 마지막 구간까지 불꽃연소 를 일으켰으며 연소불꽃은 암적색에서 적색에 가까웠다.

Fig. 4는 각 시험편의 연소과정에서 발생된 일산화탄소 발생량을 시간 단위로 나타낸 결과이다. 시중 성형숯의 일산화탄소 발생량은 연소초반 부터 현저하게 높아지는 것으로 나타났으며 이는 표면연소에 의한 불완전 연소 반응에 의한 것으로 판단된다. 연소가스 정량분석 시험 중 일산화탄소의 최대값은 마지막 $900 \mathrm{~s}$ 구간에서 반탄화 시험편이 $718 \mathrm{ppm}$ 이었으며, 시중 성형숯이 $4,096 \mathrm{ppm}$ 으로 반탄화 시험편이 시중 성형숯보다 약 50배 저감된 효과를 나타내었다. Tumuluru et al. (2010)에 의하면, 동일한 수종의 바이오매스는 탄화온도가 높고, 반응시간이 길수록 탄화물의 휘발분 함량이 낮아진다고 보고했으며, Lee (2016)의 연구결과에서 젤라틴과 아마인유를 포함하고 있는 졸참나무 반탄화 시험편은 시중 성형숯보다 휘발분이 약 $48 \%$ 높다고 밝힌 


\section{Chang-Goo LEE $\cdot$ Chang-Deuk EOM $\cdot$ Min-Ji KIM $\cdot$ Seog-Goo KANG}

점을 각각 고려하였을 때, 반탄화 시험편의 구성물은 시중 성형숯에 비해 더 많은 양의 휘발분이 함유되어 있기 때문에 비교적 완전연소반응을 나타내어 일산화탄소 함량이 두드러지게 낮은 것으로 판단된다.

이어서, Fig. 5에 각 시험편의 연소과정에서의 챔버 내 산소농도를 나타내었다. 두 가지 시험편에서 모두 연소시간의 경과에 따라 산소농도가 낮아졌으나 시중 성형숯은 연소시험 마지막까지 직선의 형태로 서서히 감소하는 반면, 반탄화 시험편은 시중 성형숯의 것보다 만곡의 형태로 비교적 크게 감소한 후, 약 $500 \mathrm{~s}$ 가 경과된 시점부터 산소농도가 거의 유지되는 것으로 나타났다.

Fig. 6에 각 시험편의 연소과정에서 발생된 질산화합물과 이산화황의 발생량을 시간 단위로 나타낸 결과이다. 반탄화 시험편 의 질산화합물은 연소초기부터 곡선의 형태를 그리며 서서히 증가하며, 약 $200 \mathrm{~s}$ 구간부터는 시중 성형숯보다 약 2 배정도 높은 것을 알 수 있었다. 이에 반해 시중 성형숯은 $100 \mathrm{~s}$ 구간부터 직선의 형태를 나타내며 값이 유지되는 것으로 나타났다. 이러한 이유는, 각 시험편의 연소양상(불꽃연소 및 표면연소)에 의한 것이며, 앞에서 언급한 반탄화 시험편의 불꽃이 암적색에서 적색에 가깝다는 점을 고려해 볼 때, 불꽃온도가 약 $525 ~ 1,000^{\circ} \mathrm{C}$ 로 고온에 준할 것으로 판단된다(Stirling, 1905). Gadi et al. (2003)에 의하면 바이오매스의 연소과정에서 높은 $\mathrm{NO}_{\mathrm{x}}$ 의 발생원인은 불꽃연소에 의한 것이며 고온에서 대기 질소와 산소의 반응으로 $\mathrm{NO}$ 의 열형성이 발생한다고 밝혔다. 이에 따라, 불꽃연소의 양상인 반탄화 시험편이 표면연소의 양상인 시중 성형숯에 비해 $\mathrm{NO}$ 의 발생량이 비교적 높게 나타난 것으로 판단된다. 이어서, 이산화황의 발생량은 두 가지 시험편 모두 매우 미미하거나 거의 발생하지 않는 것으로 나타났다.

\section{3. 일산화탄소의 발생량과 인체유해성}

이어서, Struttmann et al. (1998)과 Goldstein (2008)의 연구에서 밝힌 일산화탄소의 농도와 인체유해성에 대한 관계를 인용하여 본 연구의 두 가지 시험편의 일산화탄소 발생량을 각각 비교하였다. 이들의 연구에서는 일산화탄소의 농도가 3,200 $\mathrm{ppm}$ 일 경우 5 10분 사이에 두통, 어지러움과 메스꺼움의 증상이 나타나며, 계속하여 그 환경에 노출되어 있을 시 30 분 이내에 사망에 이르게 된다고 밝혔다. 이에 따라, 시중 성형솣의 일산화탄소 발생량의 최대값이 4,096 ppm이었다는 점을 고려하면 30 분 이내에 사망할 가능성이 높다는 것을 의미한다. 이에 반해, 반탄화 시험편의 일산화탄소 발생량의 최대값이 $718 \mathrm{ppm}$ 이었으 며 이에 유사범위의 선행연구 결과에 따르면, $800 \mathrm{ppm}$ 에서는 45 분 사이에 어지러움, 메스꺼움 및 경련의 증상이 동반되며 2시간 이내에 신체적 감각을 상실한다고 밝히고 있으나 사망에 이르지는 않는다. 따라서, 본 연구에서의 목재와 숯의 중간단계 물질인 반탄화목재와 단백질계의 젤라틴 접착제 그리고 건성 지방유인 아마인유를 이용하여 성형숯 대체재로서 제작된 반탄화 시험편은 시중 유통되고 있는 구이용 성형숯보다 연소과정에서 일산화탄소 발생량이 현저히 적으므로, 이를 악용하여 자살용도 로 사용하더라도 성공률을 비교적 크게 낮출 수 있을 것으로 예상된다.

\section{4. 결 론}

본 연구에서는 $220^{\circ} \mathrm{C}$ 에서 $300 \mathrm{~s}$ 간 반탄화처리한 졸참나무 목재칩을 젤라틴 접착제를 이용하여 냉압한 후 이에 아마인유를 도포한 시험편에 대하여, 시중에 유통되고 있는 구이용 성형숯과의 성능비교를 위해 서로간의 연료적 특성과, 연소가스 정량평가 를 실시한 결과는 다음과 같다.

1. 반탄화 시험편의 탄소함량은 약 $50 \%$ 정도로 시중 성형숯과 큰 차이가 없었으며, 수소 및 산소함량의 경우 각각 2.6 배, 2.2 배 높은 것으로 확인되었다. 질소함량은 반탄화 시험편이 시중 성형숯 보다 약 2.3 배 낮았다.

2. 반탄화 시험편의 회분함량은 시중 성형숯 보다 약 51 배 낮은 것으로 나타났으며, 고위발열량은 반탄화 시험편이 약 $14 \%$ 높은 것으로 확인되었다.

3. $900 \mathrm{~s}$ 동안의 연소과정을 통해 발생된 일산화탄소 발생량의 최대값은 반탄화 시험편의 시중 성형숯보다 약 50 배 낮아 상당한 일산화탄소 저감효과를 나타내고 있는 것을 확인하였다.

4. 본 연구의 반탄화 시험편은 2 시간 동안 노출되어도 최대 신체의 감각이 마비가 될 뿐 사망에 이르지 않는다는 점을 고려하였을 때, 이를 자살용도로 악용하더라도 성공률을 낮출 수 있는 효과를 기대할 수 있다고 시사한다. 